\author{
Andrzej Kobielski \\ Politechnika Krakowska \\ Instytut Pojazdów Szynowych \\ Stawomir Drapik \\ ZUE Kraków \\ Janusz Prusak \\ Politechnika Krakowska \\ Instytut Elektromechanicznych Przemian Energii
}

\title{
Niektóre problemy metodyki badań obciążeń wybranej kolejowej podstacji trakcyjnej metodą szeregów czasowych
}

\begin{abstract}
$W$ artykule przedstawiono kontynuacje analiz dotyczqcych oceny zmienności obciażeń wybranych kolejowych podstacji trakcyjnych. Nastepnie przypomniano niektóre uzyskane wyniki dla jednej z nich. $W$ dalszej czesści artykułu odniesiono się do adekwatności przyjętego modelu i jego parametrów $w$ świetle aproksymacji wartości średnich obciażenia podstacji wielomianami wysokiego stopnia. Stwierdzono potrzebe kontynuacji podjętych badań celem znalezienia bardziej adekwatnego sposobu aproksymacji charakterystyk analizowanych obciażeń trakcyjnych.
\end{abstract}

\section{Wprowadzenie}

W przypadku pojazdów trakcji elektrycznej lub tramwajowej energia do celów napędowych, jak i wszystkich pozostałych jest przetwarzana i dostarczana za pośrednictwem podstacji trakcyjnych. Koszty inwestycyjne, a następnie eksploatacyjne dotyczące wspomnianych podstacji mogą mieć istotne znaczenie dla wyboru rodzaju trakcji (elektryczna, spalinowa) dla danej linii. Jak już wspomniano we wcześniejszych publikacjach np. [4] stosowane metody projektowe dla podstacji trakcyjnych są właściwe, ale niekoniecznie optymalne. Warto $\mathrm{z}$ tego względu podejmować działania badawcze, które pozwolą uczynić elektryczny transport szynowy jeszcze bardziej konkurencyjnym na rynku przewozów pasażerskich i towarowych.

Znajomość przebiegu obciążenia podstacji trakcyjnej, szczególnie na etapie jej projektowania, jest zagadnieniem niezwykle istotnym ze względu m.in. na wybór aparatury przetwórczej obwodu głównego, czy też urządzeń zabezpieczających. Może to również mieć znaczenie dla oceny wielkości zużycia energii oraz formułowania strategii jej zakupu dla potrzeb trakcyjnych. Analizowanie tych obciążeń na podstawie wyników pomiarowych uzyskanych dla istniejących już podstacji pozwala zorientować się $\mathrm{w}$ ich specyfice i naturze. Stosowanie bardziej zaawansowanych metod badawczych umożliwia opis ocenianej wielkości, np. za pomocą szerszego spektrum obiektywnych wskaźników matematycznych. Autorzy niniejszego referatu w kilku wcześniejszych publikacjach [1-4,6] prezentowali już część wyników związanych $\mathrm{z}$ tym zagadnieniem. Przedstawiona poniżej analiza stanowi kontynuację podjętej tematyki.
2. Wyniki identyfikacji obciążenia kolejowej podstacji B [6]

Analizie poddano wyniki pomiarów obciążeń kolejowej podstacji B. Jest to jedna $\mathrm{z}$ trzech podstacji, która zasila duży węzeł komunikacyjny w Małopolsce. Przedstawione poniżej wyniki jej badań są kontynuacją opisanych we wcześniejszych pracach [1$4,6]$.

Podstacje $\mathbf{P}$ i $\mathbf{R}$ nie zostały $\mathrm{w}$ tym artykule uwzględnione $\mathrm{z}$ kilku istotnych powodów. Jeden $\mathrm{z}$ nich to ograniczenia objętościowe dotyczące edycji. Drugi powód to taki, że specyfika i charakterystyki obciążeń tych podstacji są zbliżone ze względu na ich bezpośrednią współpracę przy zasilaniu tego samego węzła komunikacyjnego. W związku z tym rezultaty i uwagi końcowe przedstawione w niniejszym artykule wskazują na bezcelowość realizacji bardzo pracochłonnych, licznych eksperymentów cyfrowych.

Do obliczeń wykorzystano pomiary obciążeń trakcyjnych dokonywanych $\mathrm{w}$ czasie trwania szczytu przewozowego porannego (godz. 6.00-8.00).

Dla potrzeb wspomnianej analizy ww. obciążenia trakcyjne zostały przekształcone poprzez zmniejszenie ich częstotliwości próbkowania z wartości $2 \mathrm{kHz}$ (rzeczywista częstotliwość pomiarów) do kilku mniejszych wartości częstotliwości. Zabiegi te miały na celu m.in. zmniejszenie pojemności danych do obróbki matematycznej. Próbkowanie 2-godzinnego szczytu z częstotliwością $2 \mathrm{kHz}$ powoduje, ze zbiór zarejestrowanych danych zawiera $1,44 \times 10^{7}$ elementów. Konieczność ta wynikała $\mathrm{z}$ własności dysponowanych przez autorów niniejszej pracy czasowego, 
środków hardware'owych i software'owych. Zaprezentowane poniżej wyniki analiz wskazują wpływ takiego postępowania na uzyskiwane rezultaty w zakresie parametrów modeli szeregów czasowych.

$\mathrm{W}$ niniejszej pracy przedstawiono wyniki badań przekształconych (przetworzonych) przebiegów o częstotliwości $1 \mathrm{~Hz}, 10 \mathrm{~Hz}$ oraz $50 \mathrm{~Hz}$.

Dane do analizy dla wybranych częstotliwości przygotowano wg dwóch procedur $\mathrm{w}$ każdym przypadku. Pierwszy z nich polegał na obliczeniu wartości średnich $\mathrm{z}$ przedziałów czasowych wynikających $\mathrm{z}$ założonych częstotliwości. Zaś $\mathrm{w}$ wariancie drugim brano pod uwagę wartości maksymalne $\mathrm{z}$ tych samych przedziałów.

W uprzedniej pracy autorów niniejszego artykułu [6] wykazano, iż z prawdopodobieństwem 0,95 przebieg obciążenia kolejowej podstacji trakcyjnej $\mathbf{B}$ można opisać za pomocą szeregu czasowego w postaci procesu autoregresji drugiego rzędu - AR(2), lub w postaci ogólniejszej jako proces $\operatorname{ARIMA}(2,0,0)$

Model autoregresji rzędu $p$ oznaczany symbolem $\mathbf{A R}(\mathrm{p})$, opisany równaniem:

$$
\mathrm{x}_{\mathrm{t}}=\mathrm{c}_{1}+\varphi_{1} \mathrm{x}_{\mathrm{t}-1}+\varphi_{2} \mathrm{x}_{\mathrm{t}-2}+\ldots .+\varphi_{\mathrm{p}} \mathrm{x}_{\mathrm{t}-\mathrm{p}}+\mathrm{a}_{\mathrm{t}}
$$

gdzie:

$\mathrm{c}_{1}$ - stała,

$\varphi_{\mathrm{n}}$ - współczynniki wagowe modelu szeregu czasowego, $\mathrm{n} \leq \mathrm{p}$,

$a_{\mathrm{t}} \quad$ - nieskorelowana zmienna losowa o rozkładzie normalnym $\left(0, \sigma_{\mathrm{a}}{ }^{2}\right)$, tzw. biały szum.
Na powyższym wykresie funkcji autokorelacji cząstkowej jedynie dwa prążki wystają istotnie poza zakres przedziału ufności na poziomie 0,95 (linie przerywane). Z czego wynika, że badany szereg czasowy jest procesem drugiego rzędu i to procesem autoregresji $\mathbf{A R}(2)$. Opisy matematyczne funkcji autokorelacji i autokorelacji cząstkowej podano szeroko w pracy [6] i nie zamieszczono ich ze względu na ograniczenia objętościowe artykułu.

Potwierdza to charakter i kształt wykresu gęstości widmowej mocy (periodogramu) obserwowanego przebiegu obciążenia podstacji $\mathbf{B}$, który przedstawiono na poniższym rys.2. Podobnie jak w powyższej uwadze nie zamieszczono w artykule dość złożonego opisu matematycznego funkcji periodogramu.

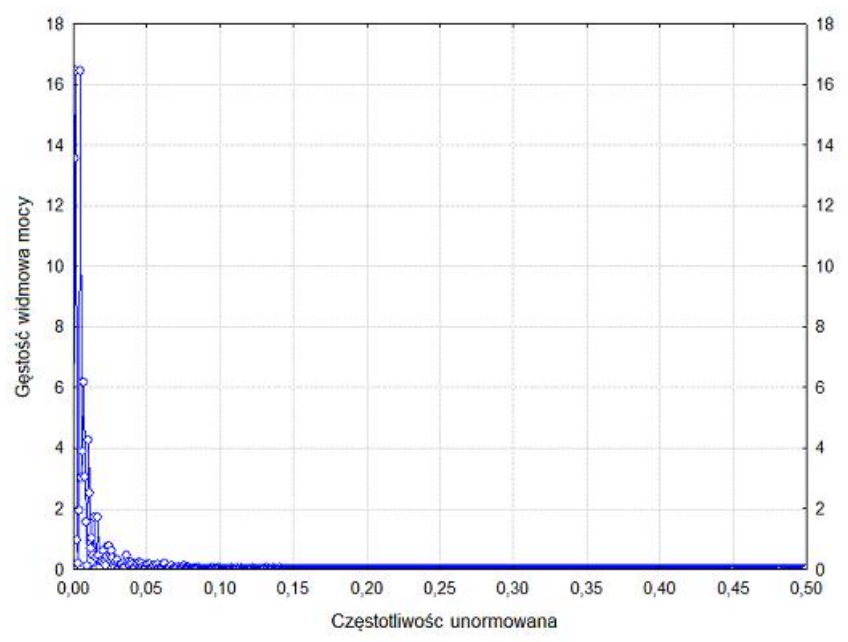

Rys.2. Periodogram obciążenia podstacji trakcyjnej B (szczyt poranny) [7].

COYY. S.E.

$+, 984,0277$

$-, 154,0277$

$-053,0277$

$-, 021,0277$

$+, 005,0277$

$-006,0277$

$+, 002,0277$

$+, 021,0277$

$+, 023,0277$

$-, 006,0277$

$-016,0277$

$+, 033,0277$

$-, 020,0277$

$+, 009,0277$

$-001,0277$

$+, 015.0277$

$-, 030,0277$

$+, 007,0277$

$+, 014,0277$

$+, 007,0277$

$+, 033,0277$

$-, 040,0277$

$+, 009,0277$

$-, 032,0277$

$+, 005,0277$

$+, 026,0277$

$-003,0277$

$+, 026,0277$

$-019,0277$

$-, 009.0277$

$-1,0$

|
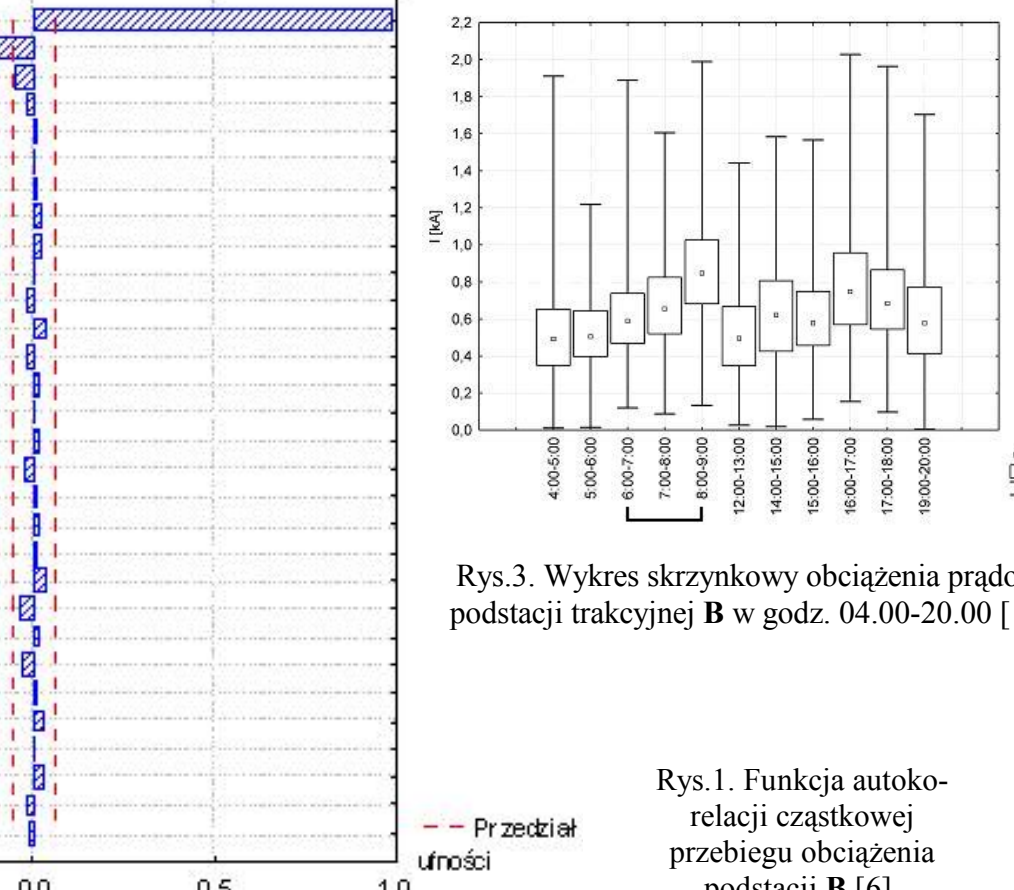

Mediana

Rys.3. Wykres skrzynkowy obciążenia prądowego podstacji trakcyjnej B w godz. 04.00-20.00 [1,2,4].

- - Pr zectziat uności
Rys.1. Funkcja autokorelacji cząstkowej przebiegu obciążenia podstacji B [6].

$W$ artykule zachowano symbolike anglojezyczna stosowana w literaturze: model AR (AutoRegressive model - model autoregresji), model ARIMA (A utoRegressive-Integrated Moving Average model - scalkowany model autoregresji i średniej ruchomej). 
Na powyższym rys.3 przedstawiono wykres skrzynkowy obciążenia prądowego podstacji trakcyjnej B w godz. 04.00-20.00. Analizowany poranny szczyt przewozowy jest zaznaczony klamra.

Jednym ze skutecznych sposobów oceny własności statystycznych populacji wyników pomiarów jest wykorzystanie tzw. wykresów skrzynkowych (Rys.3), zwanych też w literaturze polskiej jako pudełkowe lub „skrzynką z wąsami” (ang. Box-andWhisker Plot, Boxplot), których twórcą był J.W. Tukey (,Exploratory Data Analysis”, AddisonWesley, MA 1977).

Wykresy te, prócz informacji statystycznych, pozwalają także na interpretację graficzną wyników pomiarów.

Cechą charakterystyczną wykresów skrzynkowych jest przedstawienie w zwięzłej graficznej postaci usytuowanie 50\% wyników pomiarów ograniczonych wymiarem pionowym „skrzynki” względem mediany (kwadrat $\mathrm{w}$ jej środku) i zarejestrowanych ekstremalnych wartości pomiarowych, zwanych ,wąsami”.

\section{Analiza adekwatności modelu i jego parametrów w świetle aproksymacji wielomianowej}

Poniższa analiza dotyczy modelu wyjściowego obciążenia kolejowej podstacji B zidentyfikowanego jako model autoregresji rzędu drugiego $\mathbf{A R}(2)$. Przy czym podstawowym zadaniem autorów niniejszego artykułu było wyznaczenie wartości współczynników modelu, w szczególności zaś - podobieństwa charakteru procesu na podstawie m.in. wykresów funkcji autokorelacji cząstkowej odniesionych do bazowego wykresu zamieszczonego na rys.1.

Zgodnie z założeniem (rozdz.2) analiza była przeprowadzona na plikach przekształconych (przetworzonych) przebiegów obciążenia trakcyjnego podstacji B o częstotliwościach $1 \mathrm{~Hz}, 10 \mathrm{~Hz}$ oraz $50 \mathrm{~Hz}$ a do ich aproksymacji wybrano w pierwszej kolejności aproksymację wielomianową stopnia 16-go oraz 32-go.

Poniżej przedstawiono stosowne przypadki założone przez autorów do weryfikacji samej metody badań a w szczególności efektywności aproksymacji wielomianami wysokiego stopnia:

a. częstotliwość $1 \mathrm{~Hz}$, wielomian stopnia 16-go,

b. częstotliwość $1 \mathrm{~Hz}$, wielomian stopnia 32-go,

c. częstotliwość $10 \mathrm{~Hz}$, wielomian stopnia 16go,

d. częstotliwość $10 \mathrm{~Hz}$, wielomian stopnia 32go,

e. częstotliwość $50 \mathrm{~Hz}$, wielomian stopnia 16go,

f. częstotliwość $50 \mathrm{~Hz}$, wielomian stopnia 32go.

Na poniższych wykresach o numeracji parzystej (rys.4, 6, 8,10, 12 i 14) przedstawiono przebieg aproksymowanej średniej wartości obciążenia podstacji B (krzywa ciagła) na tle ciagu pomiarowego w szczycie porannym (godz. $6.00-8.00$ ).

\section{Przypadek a)}

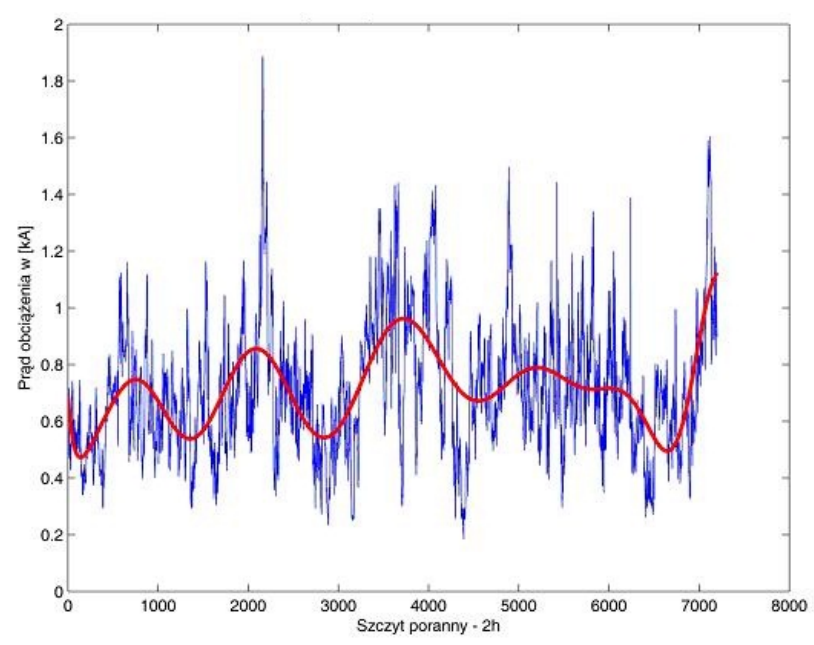

Rys.4. Aproksymacja średniej wartości obciążenia podstacji B dla częstotliwości $1 \mathrm{~Hz}$ wielomianem stopnia 16-go.

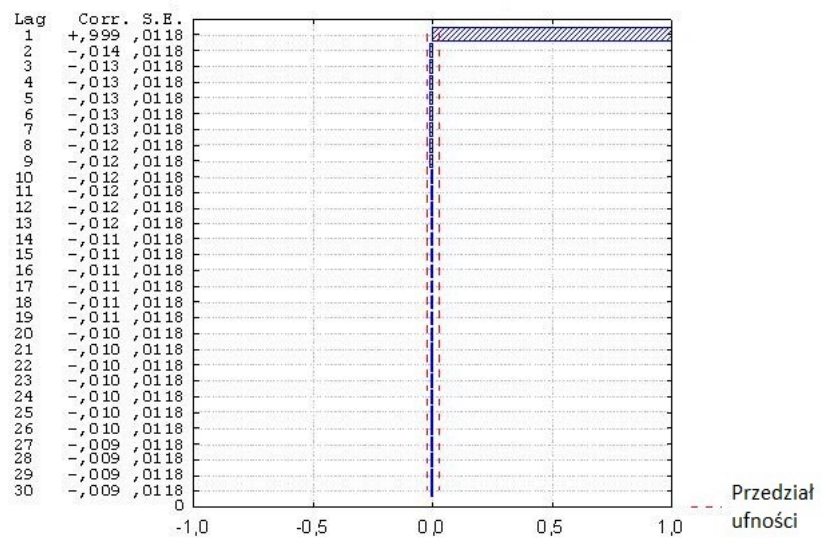

Rys.5. Funkcja autokorelacji cząstkowej aproksymowanej średniej wartości obciążenia podstacji B dla częstotliwości $1 \mathrm{~Hz}$ wielomianem stopnia 16-go.

Identyfikacja przebiegu aproksymowanej średniej wartości obciążenia podstacji B (rys.4) jako szeregu czasowego dała w wyniku oszacowanie jej jako procesu autoregresji rzędu 1-go, AR(1) - (rys.5), którego jeden z parametrów modelu szeregu czasowego opisanego wzorem (1) jest równy $\varphi_{1}=0,999929$.

Dla potwierdzenia tego faktu przeprowadzono eksperyment polegający na założeniu, że przebieg powyżej aproksymowanej średniej wartości obciążenia podstacji jest modelem $\mathbf{A R}(2)$. W wyniku zastosowania stosownej procedury pakietu STATISTICA uzyskano następujące wartości parametrów tego modelu: $\varphi_{1}=0,997054$ oraz $\varphi_{2}=0,002943$. Wartość parametru $\varphi_{2}$ stanowi $0,2952 \%$ wartości parametru $\varphi_{1}$. Potwierdza to fakt, że poprzednie oszacowanie w postaci modelu AR(1) jest poprawne.

Zatem dla przypadku a) występuje brak zgodności z bazowym modelem AR(2), wynikającym 
z jego oszacowania na podstawie wyników pomiarów obciążenia podstacji B $\mathrm{W}$ porannym szczycie przewozowym.

\section{Przypadek b)}

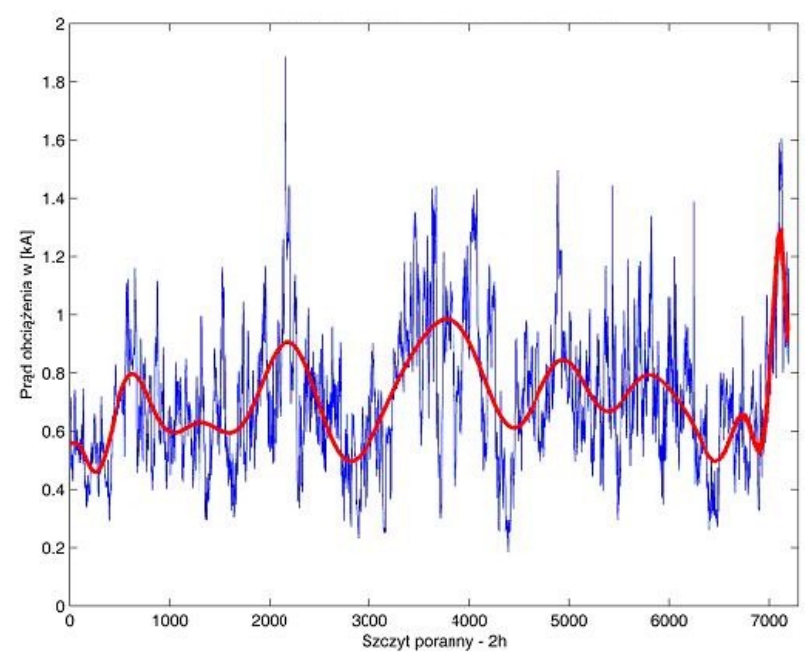

Rys.6. Aproksymacja średniej wartości obciążenia podstacji B dla częstotliwości $1 \mathrm{~Hz}$ wielomianem stopnia 32-go.

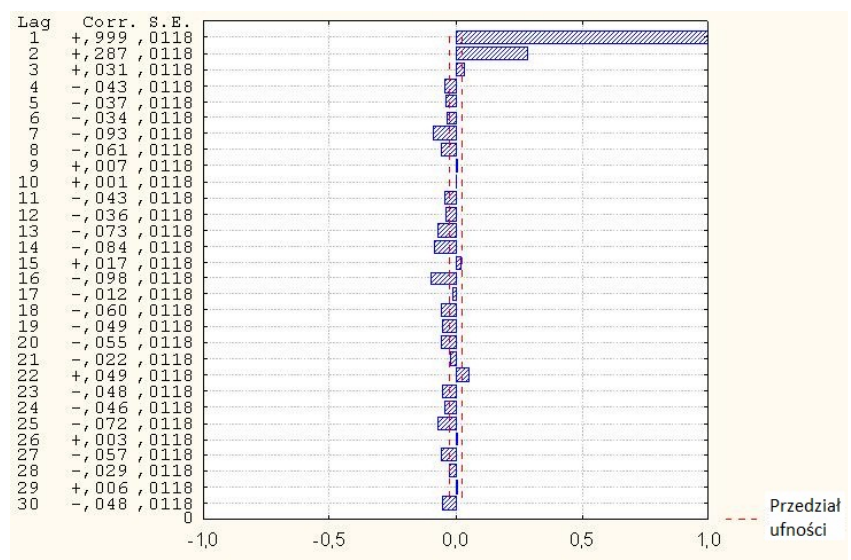

Rys.7. Funkcja autokorelacji cząstkowej aproksymowanej średniej wartości obciążenia podstacji $\mathbf{B}$ dla częstotliwości $1 \mathrm{~Hz}$ wielomianem stopnia 32-go.

Kształt funkcji autokorelacji cząstkowej będącej wynikiem identyfikacji przebiegu aproksymowanej średniej wartości obciążenia podstacji B (rys.7) jako szeregu czasowego dała $\mathrm{w}$ rezultacie oszacowanie jej jako procesu typu ARIMA $(p, d, q)$ o niezerowych jego współczynnikach. Wyklucza to zgodność z bazowym modelem AR(2), wynikającym z jego oszacowania na podstawie wyników pomiarów obciążenia podstacji $\mathbf{B}$ w porannym szczycie przewozowym.

Warto jednak zauważyć, że aproksymowana średnia wartość obciążenia podstacji $\mathbf{B}$ wielomianem stopnia 32-go daje (z graficznego punktu widzenia) lepsze jej przybliżenie w stosunku do wyników pomiarów obciążenia podstacji niż w przypadku aproksymacji wielomianem stopnia 16 -go (rys.4 oraz 6).

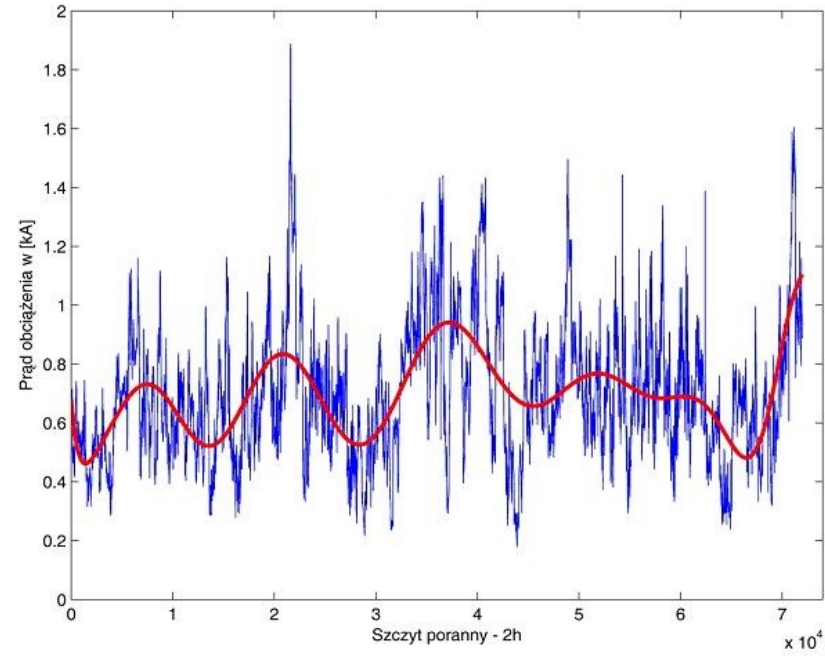

Rys.8. Aproksymacja średniej wartości obciążenia podstacji B dla częstotliwości $10 \mathrm{~Hz}$ wielomianem stopnia 16-go.

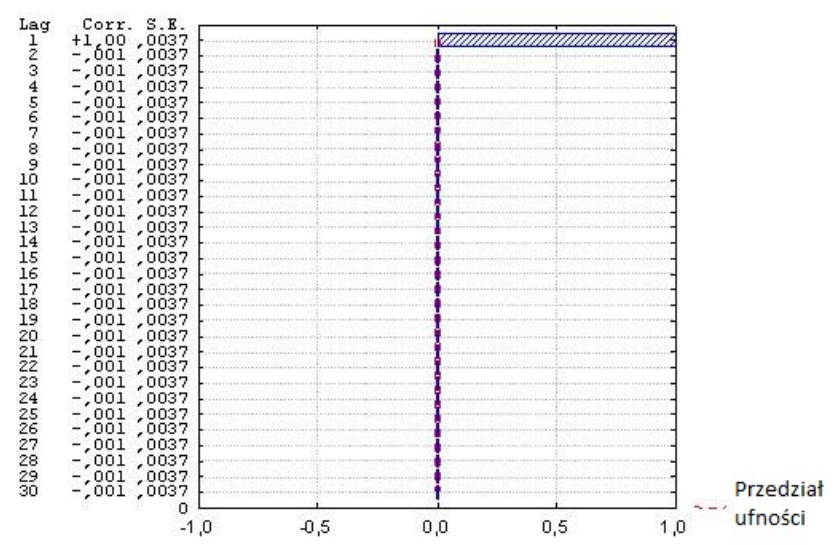

Rys.9. Funkcja autokorelacji cząstkowej aproksymowanej średniej wartości obciążenia podstacji B dla częstotliwości $10 \mathrm{~Hz}$ wielomianem stopnia 16-go.

Kształt funkcji autokorelacji cząstkowej aproksymowanej średniej wartości obciążenia podstacji B dla częstotliwości próbkowania $10 \mathrm{~Hz}$ wielomianem stopnia 16-go świadczy, że posiada ona cechy modelu autoregresji 1-go rzędu AR(1) - analogicznie jak w analizowanym powyżej przypadku a) przedstawionym na rys.5. Dla rozpatrywanego przypadku c) jeden z parametrów modelu szeregu czasowego opisanego wzorem (1) jest równy $\varphi_{1}=0,999937$, co oznacza bardzo dużą zgodność z przypadkiem a), dla którego wartość współczynnika modelu AR(1) wynosi $\varphi_{1}=0,999929$ (różnica na dwóch ostatnich miejscach).

Zatem dla rozpatrywanego przypadku (analogicznie jak w przypadku a), występuje brak zgodności z bazowym modelem AR(2), wynikającym z jego oszacowania na podstawie wyników pomiarów obciążenia podstacji B w porannym szczycie przewozowym.

\section{Przypadek c)}




\section{Przypadek d)}

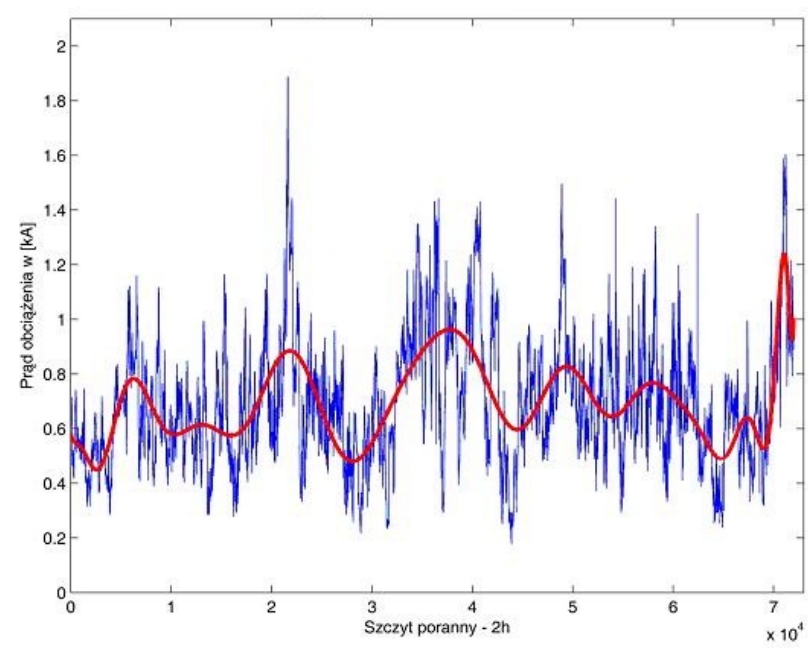

Rys.10. Aproksymacja średniej wartości obciążenia podstacji B dla częstotliwości $10 \mathrm{~Hz}$ wielomianem stopnia 32-go.

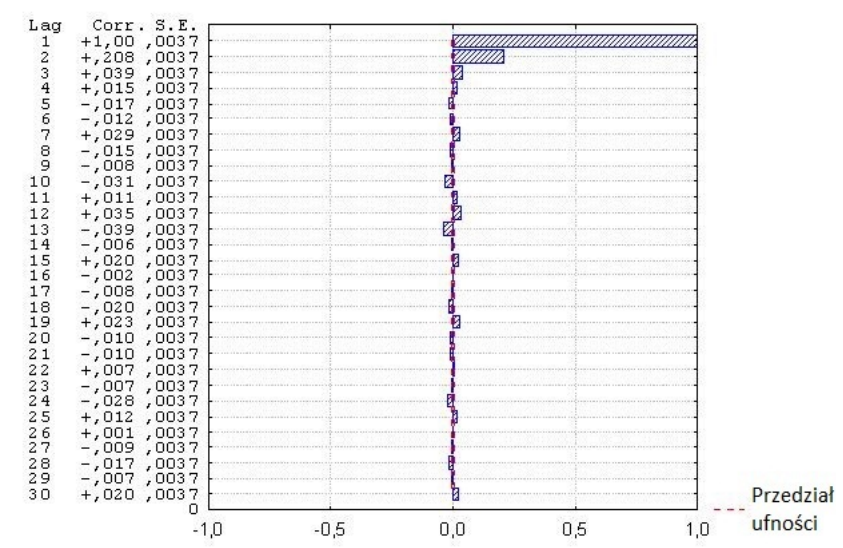

Rys.11. Funkcja autokorelacji cząstkowej aproksymowanej średniej wartości obciążenia podstacji $\mathbf{B}$ dla częstotliwości $10 \mathrm{~Hz}$ wielomianem stopnia 32-go.

Rozpatrywany przypadek d) charakteryzuje się bardzo zbliżonymi cechami jak rozpatrywany powyżej przypadek b).

Podobnie jak w przypadku b) kształt funkcji autokorelacji cząstkowej będącej wynikiem identyfikacji przebiegu aproksymowanej średniej wartości obciążenia podstacji B (rys.11) jako szeregu czasowego sugeruje jej estymację jako procesu typu ARIMA $(p, d, q)$ o jego niezerowych współczynnikach.

Podobnie również jak w przypadku b) występuje niezgodność z bazowym modelem $\mathbf{A R}(2)$, wynikającym $\mathrm{z}$ jego oszacowania na podstawie wyników pomiarów obciążenia podstacji $\mathbf{B} \mathrm{w}$ porannym szczycie przewozowym.

Podobnie także jak w przypadku b) można zauważyć, że aproksymowana średnia wartość obciążenia podstacji $\mathbf{B}$ wielomianem stopnia 32-go daje (z graficznego punktu widzenia) lepsze jej przybliżenie w stosunku do wyników pomiarów obciążenia podstacji niż w przypadku aproksymacji wielomianem stopnia 16-go (rys.8 oraz 10).
Jeśli zaś zaniedbać prążki autokorelacji cząstkowej po prążku nr 3,to wówczas estymowany model średniej wartości obciążenia podstacji B przyjąłby postać modelu autoregresji rzędu 3-go $\mathbf{A R}(3)$, i wówczas jego współczynniki miałyby wartości: $\varphi_{1}=0,905954, \varphi_{2}=0,090674$ oraz $\varphi_{3}=$ 0,003372 , co również jest niezgodne $\mathrm{z}$ bazowym modelem AR(2), wynikającym z jego oszacowania na podstawie wyników pomiarów obciążenia podstacji $\mathbf{B}$.

\section{Przypadek e)}

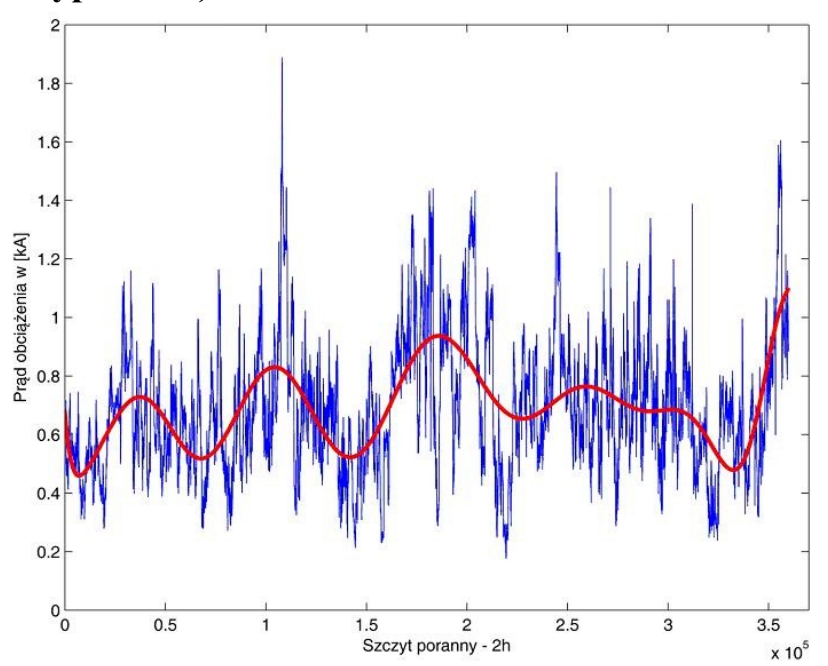

Rys.12. Aproksymacja średniej wartości obciążenia podstacji B dla częstotliwości $50 \mathrm{~Hz}$ wielomianem stopnia 16-go.

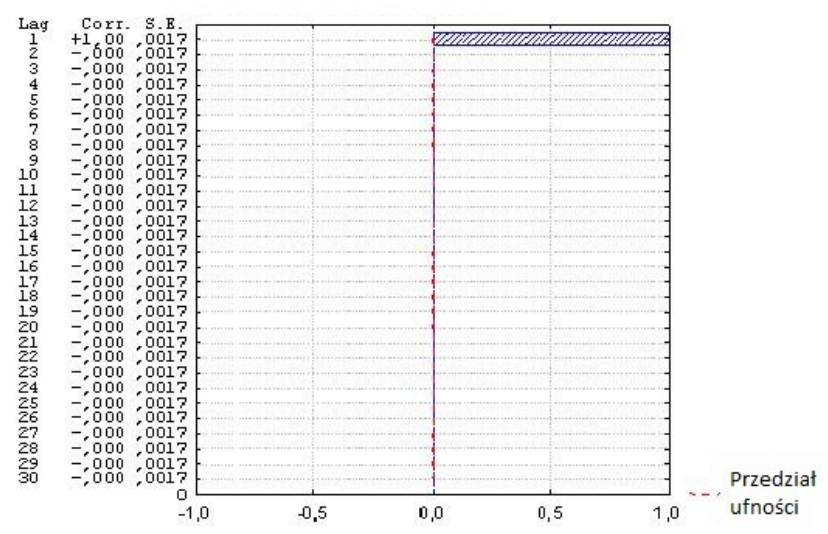

Rys.13. Funkcja autokorelacji cząstkowej aproksymowanej średniej wartości obciążenia podstacji B dla częstotliwości $50 \mathrm{~Hz}$ wielomianem stopnia 16-go.

Analiza wykresów dla warunków przyjętych dla rozpatrywanego przypadku e) prowadzi do analogicznych wniosków jak w przypadku a) oraz przypad$\mathrm{ku} \mathrm{c})$.

Przypadek d) daje się zatem opisać modelem autoregresji 1-rzędu AR(1), zaś wartość estymowanego parametru modelu wynosi $\varphi_{1}=0,999944$.

Można zatem zauważyć, że niezależnie od częstotliwości próbkowania średniej wartości obciążenia podstacji trakcyjnej $\mathbf{B}(1 \mathrm{~Hz}, 10 \mathrm{~Hz}, 50 \mathrm{~Hz})$, jej aproksymacja wielomianem stopnia 16-go powoduje estymację tego samego modelu szeregu czasowego autoregresji rzędu 1-go $\mathbf{A R}(1)$ o parametrach $\varphi_{1}$ różniących się od siebie wartościami dopiero na 5-tym i 6-tym miejscu. 


\section{Przypadek f)}

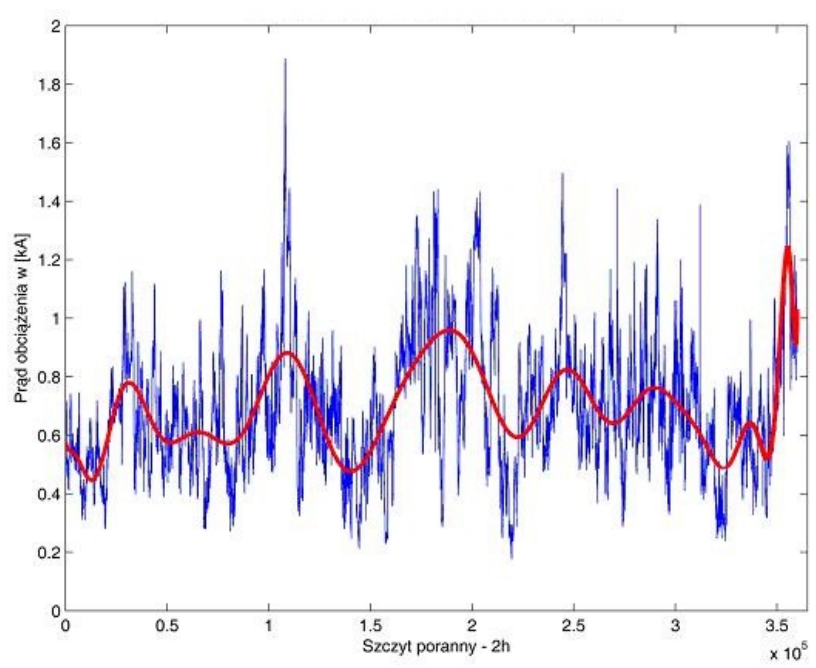

Rys.14. Aproksymacja średniej wartości obciążenia podstacji B dla częstotliwości $50 \mathrm{~Hz}$ wielomianem stopnia 32-go.

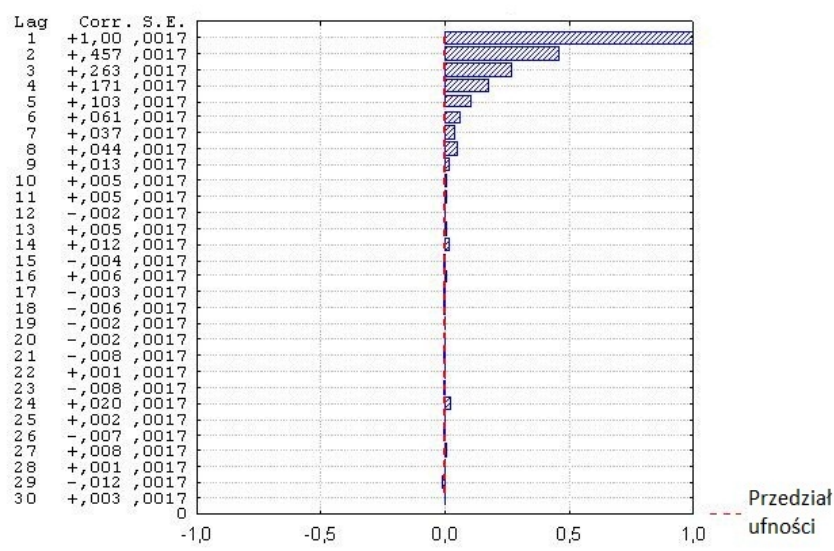

Rys.15. Funkcja autokorelacji cząstkowej aproksymowanej średniej wartości obciążenia podstacji $\mathbf{B}$ dla częstotliwości $50 \mathrm{~Hz}$ wielomianem stopnia 32-go.

Analizowany przypadek f) posiada odmienne cechy od rozpatrywanego powyżej przypadku b) oraz przypadku d), których charakterystyki były do siebie zbliżone.

Kształt funkcji autokorelacji a szczególnie funkcji autokorelacji cząstkowej (rys.15) pozwala przyjąć założenie, że średnią wartość obciążenia trakcyjnego podstacji B można opisać za pomocą modelu autoregresji rzędu 8-go AR(8). Jednak jak przytoczono w pracach [6,7] za (Box G.E.P., Jenkins G.M.: Analiza szeregów czasowych. Prognozowanie i sterowanie, Państwowe Wydawnictwo Naukowe, Warszawa 1983), do rzadkości należą szeregi czasowe, których modele autoregresji są rzędu wyższego niż $\operatorname{AR}(3)$.

Zakładając jednakże estymację średniej wartości obciążenia trakcyjnego podstacji B modelem autoregresji rzędu 8-go $\mathrm{AR}(8)$, to wartości wspó1czynników tego modelu są równe:

$\varphi_{1}=0,513914, \varphi_{2}=0,251447, \varphi_{3}=0,117132, \varphi_{4}=$ 0,067231 ,

$\varphi_{5}=0,027292, \varphi_{6}=0,008696, \varphi_{7}=-0,002344, \varphi_{8}=$ 0,016628 .

\section{Wnioski i uwagi końcowe}

Zaprezentowane powyżej wyniki analiz wskazują na szczególną specyfikę zmienności obciążeń trakcyjnych, które $z$ wielkimi trudem poddają się ocenie $\mathrm{z}$ zastosowaniem metody aproksymacji wielomianowej badanych szeregów czasowych.

W szczególności:

1) otwartym zagadnieniem jest wybór częstotliwości pomiaru badanego obciążenia podstacji trakcyjnej,

2) zmiany częstotliwości badanych przebiegów obciążeń trakcyjnych podstacji nie zmieniały w istotny sposób ich wartości średnich - różnice nie przekraczały $4 \%$ (pozostałych parametrów elektrycznych i statystycznych nie brano pod uwagę na obecnym etapie badań),

3) przy wyższych częstotliwościach badanych przebiegów obciążeń trakcyjnych podstacji pojawia się zjawisko niestabilności wielomianów aproksymacyjnych,

4) ze wzrostem częstotliwości analizowanych przebiegów pojawiają się znaczne różnice $\mathrm{w}$ kształcie funkcji autokorelacji cząstkowych w odniesieniu do autokorelacji cząstkowej będącej wynikiem oszacowania rzędu autoregresji $\mathbf{A R}(2)$ szeregu czasowego wynikającego $\mathrm{z}$ analizy pierwotnego pomiaru $(2 \mathrm{kHz}) \mathrm{w}$ szczycie 2-godzinnym podstacji B (vide rys.1);

5) prognozowanie zmienności obciążeń trakcyjnych nawet dla krótkich odcinków czasowych nie jest jeszcze możliwe na obecnym etapie badań.

Wobec niesatysfakcjonujących rezultatów zastosowania aproksymacji wielomianowej, jak to wynika z przestawionych przykładów, istnieje konieczność poszukiwania bardziej skutecznej metody aproksymacji dla uzyskania możliwie optymalnej zgodności z procesem autoregresji rzędu drugiego $\mathbf{A R}(2)$.

Kontynuacja badań powinna doprowadzić do sformułowania takich procedur, które pozwola z zadawalającą dokładnością określać spodziewaną zmienność obciążeń podstacji trakcyjnych.

Dzięki temu będą istniały uzasadnione podstawy m.in. dla:

1) doskonalenia metod projektowych celem bardziej precyzyjnego (optymalnego) doboru urządzeń przetwórczych (zespołów prostownikowych) rozdzielczych i zabezpieczających dla podstacji trakcyjnych, 
2) dla podejmowania uzasadnionych decyzji o sposobie zakupu energii elektrycznej dla potrzeb trakcyjnych,

3) dla projektantów i konstruktorów nowych generacji urządzeń wyposażenia podstacji trakcyjnych, parametrach znamionowych bardziej dostosowanych do charakteru zmienności obciążeń trakcyjnych,

4) dla zespołów ekspertów tworzących nowe przepisy (normy, standardy, procedury), z zakresu znamionowania urządzeń dla wyposażenia podstacji trakcyjnych.

\section{Literatura}

[1] Drapik S., Kobielski A., Prusak J.: Selected issues of traction substation load variability. [w] Modern Electric Traction. Power Supply (red. K. Karwowski, A. Szelag), Chapter 5, Gdansk University of Technology, Gdańsk 2009.

[2] Drapik S., Kobielski A., Prusak J.: Wybrane aspekty zmienności obciażeń kolejowych podstacji trakcyjnych. $9^{\text {th }}$ International Conference MET '2009, Gdańsk, September 24-26, 2009, Poland, str. 171.
[3] Drapik S., Kobielski A., Prusak J.: Wybrane aspekty zmienności obciażeń kolejowych podstacji trakcyjnych. Technika Transportu Szynowego (tts), $n r$ 4/2010.

[4] Drapik S., Kobielski A., Prusak J.: Fluktuacja obciązeń podstacji trakcyjnych $w$ ujęciu teorii szeregów czasowych. Technika Transportu Szynowego (tts), $n r$ 7-8/2010.

[5] Kobielski A., Prusak J., Popczyk M.: Ocena procedur pomiarowych na przykładzie zmienności kolejowych obciażeń trakcyjnych. [w] Czasopismo Techniczne Elektrotechnika, $n r$ 1-E/2009, zeszyt 15, rok 106, Wydawnictwo Politechniki Krakowskiej.

[6] Drapik S., Kobielski A., Prusak J.: Analiza zmienności obciażeń trakcyjnych $w$ ujęciu szeregów czasowych. XIV Konferencja Naukowa Trakcji Elektrycznej SEMTRAK 2010, Zakopane, październik 2010, str.27.

[7] Drapik S., Kobielski A., Prusak J.: Analiza zmienności obciażeń trakcyjnych $w$ ujęciu szeregów czasowych. [w] Czasopismo Techniczne - Elektrotechnika, Wydawnictwo Politechniki Krakowskiej (w druku). 